\title{
A New Species of the Genus Lepidodactylus Fitzinger (Squamata: Gekkonidae) from the Mortlock Islands, Chuuk State, Federated States of Micronesia ${ }^{1}$
}

\author{
Donald W. Buden ${ }^{2}$
}

\begin{abstract}
A new species in the Group II complex of the gekkonid lizard genus Lepidodactylus Fitzinger is described based on recently collected material from Namoluk Atoll, Mortlock Islands, Chuuk State, Federated States of Micronesia. Lepidodactylus oligoporus Buden, n. sp., is distinguished from other members of Group II by differences in the numbers of midbody scale rows (130-134), fourth-toe scansors (15-19), interorbital scales (34-35), and precloacal/femoral pore-bearing scales $(12-15)$ and by the lack of cloacal spurs and the presence of a moderate amount of webbing between the toes. In body size and scutellation, it most resembles L. novaeguineae Brown \& Parker from New Guinea and $L$. pulcher Boulenger from the Admiralty Islands.
\end{abstract}

The geKKonid genus Lepidodactylus Fitzinger includes 31 species (Uetz et al. 2005) that for the most part are distributed from Southeast Asia southward and eastward to the Indo-Australian Archipelago and Oceania (Bauer and Henle 1994, Ota et al. 2000, Zug et al. 2003). With the exception of the parthenogenetic L. lugubris (Dumeril \& Bibron) and its two parental species (Radtkey et al. 1995, Ineich 1999), the species each have rather limited distributions and are often found on only one or a few small island groups (Ota et al. 1995, 2000, Zug et al. 2003). Three infrageneric species groups proposed by Brown and Parker (1977) are recognized based largely on the morphology of subdigital scansors: Group I species (pumilus group) completely lack deeply notched or divided scansors, Group II species ( $g u p p y i$ group) have only a few of the subterminal scansors divided or notched, and Group III

${ }^{1}$ Manuscript accepted 18 August 2006.

2 Division of Natural Sciences and Mathematics, College of Micronesia-FSM, P.O. Box 159, Kolonia, Pohnpei, Federated States of Micronesia 96941 (e-mail: don_buden@comfsm.fm).

Pacific Science (2007), vol. 61, no. 3:407-414 (C) 2007 by University of Hawai'i Press

All rights reserved species (lugubris group) have the terminal as well as several subterminal scansors divided or notched. Among the 10 species in Group II (see Zug et al. 2003), L. paurolepis Ota, Fischer, Ineich \& Case from Palau is the only one recorded from the Caroline Islands, a chain of high volcanic islands and many more low coralline atolls spanning approximately 3,200 km across the west-central $\mathrm{Pa}$ cific Ocean from Palau in the west to Kosrae in the east (Figure 1).

Specimens of a Group II Lepidodactylus were recently collected from Namoluk Atoll, Mortlock Islands, Chuuk, Micronesia, in the central Carolines. They differ from L. paurolepis and all other Group II members by a combination of morphological character states and are herein described as a new species.

\section{MATERIALS AND METHODS}

Five specimens of Group II Lepidodactylus were recently collected during a survey of terrestrial vertebrates in the Mortlock Islands. They were fixed in 10\% formalin and preserved in $35 \%$ isopropanol. Measurements were taken to the nearest $0.1 \mathrm{~mm}$ using dial calipers (Helios) graded in $0.05-\mathrm{mm}$ increments. Characters selected for measurement are defined in Zug et al. (2003); scansors are counted in the manner of Ota et al. (1995) and Zug et al. $(2003)=$ total lamellae of 


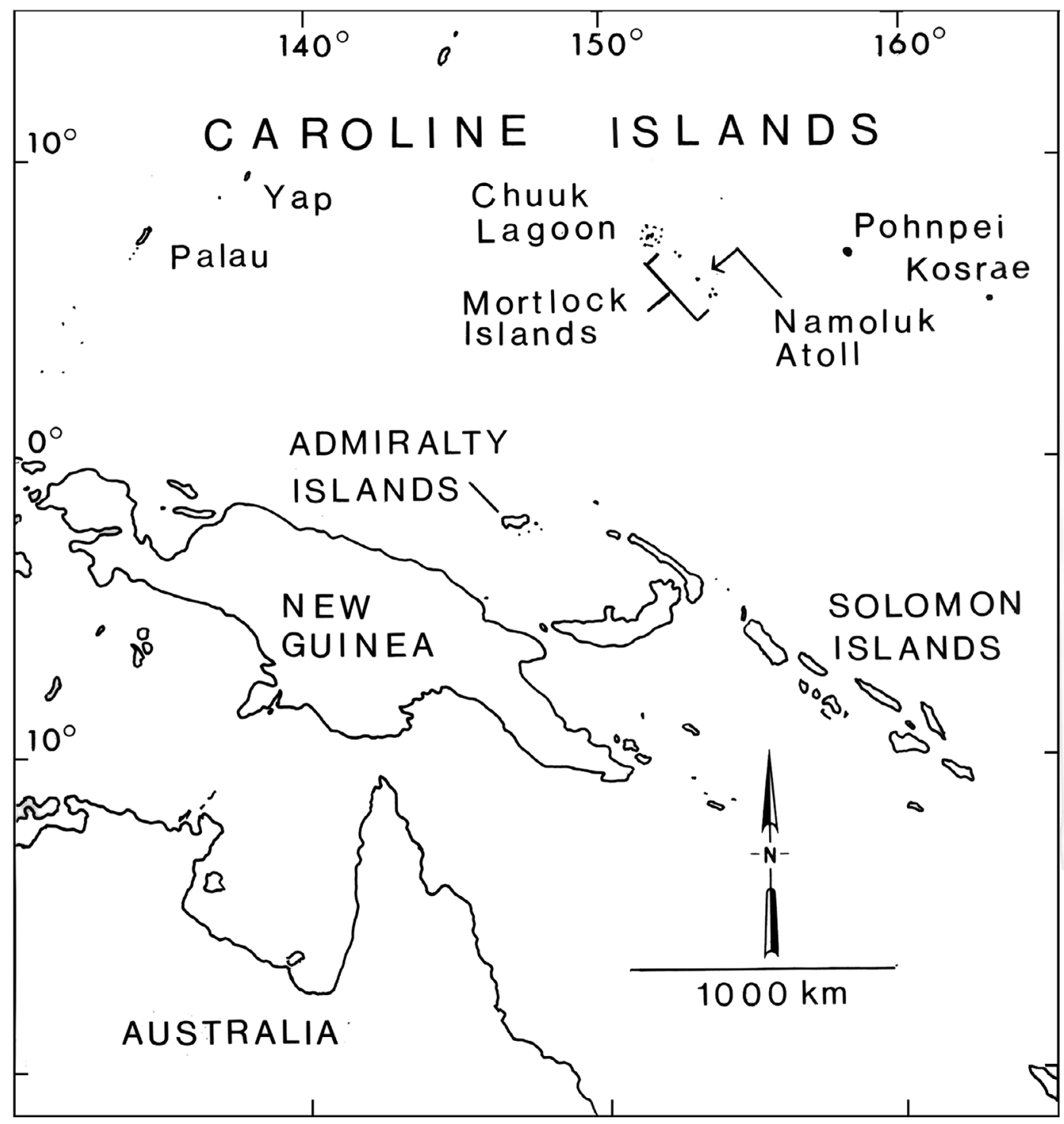

Figure 1. Location map of Namoluk Atoll, Mortlock Islands, and surrounding islands.

Bergmann and Russell (2003). Comparisons with other Group II species were based largely on data from literature. Sexual maturity in the three males was determined by the presence or absence of a complete series of actively secreting pore-scales; the two females, both larger than the largest (and mature) male, are considered adults. Institutional abbreviations are as follows: cas (California Academy of Sciences), сом (College of Micronesia), MCz (Museum of Comparative Zoology, Harvard University), and вмNH (The Natural History Museum, London, formerly British Museum of Natural History). 


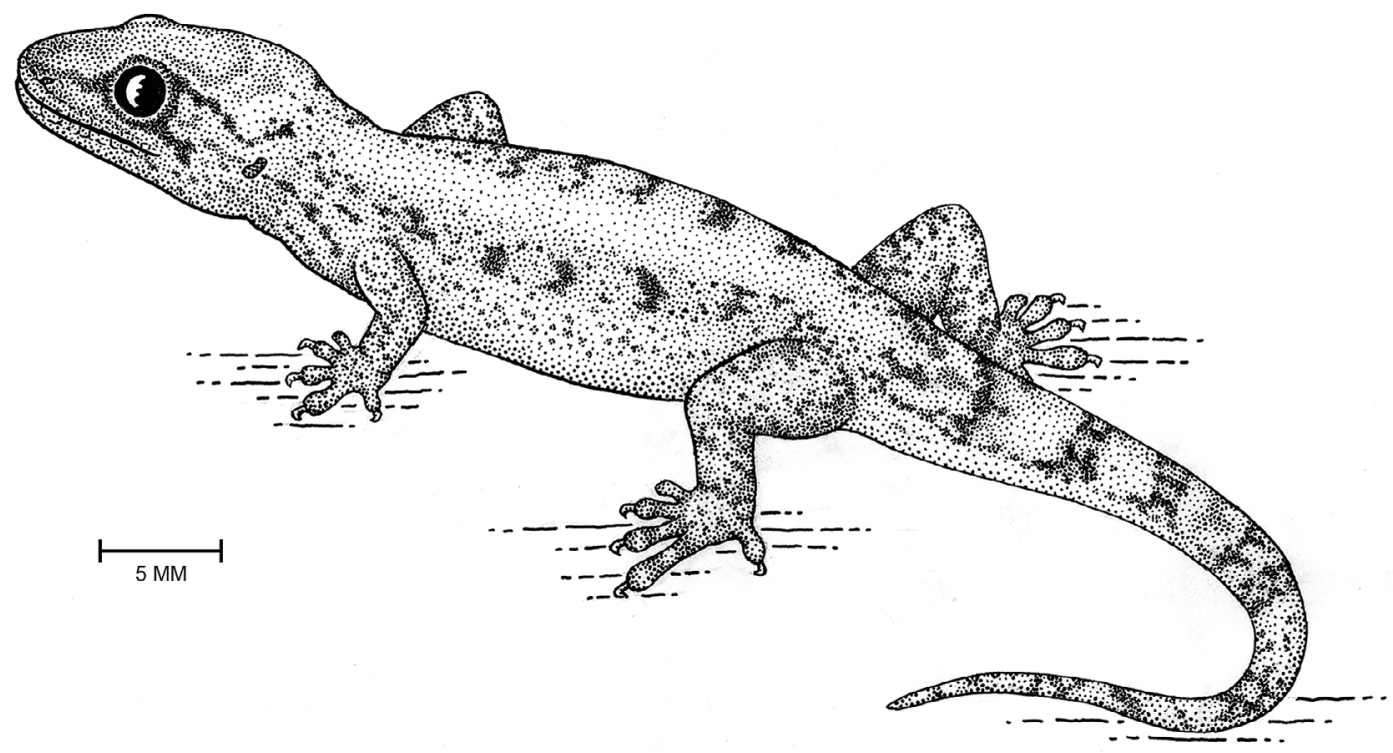

Figure 2. Holotype of L. oligoporus, MCZ R184388.

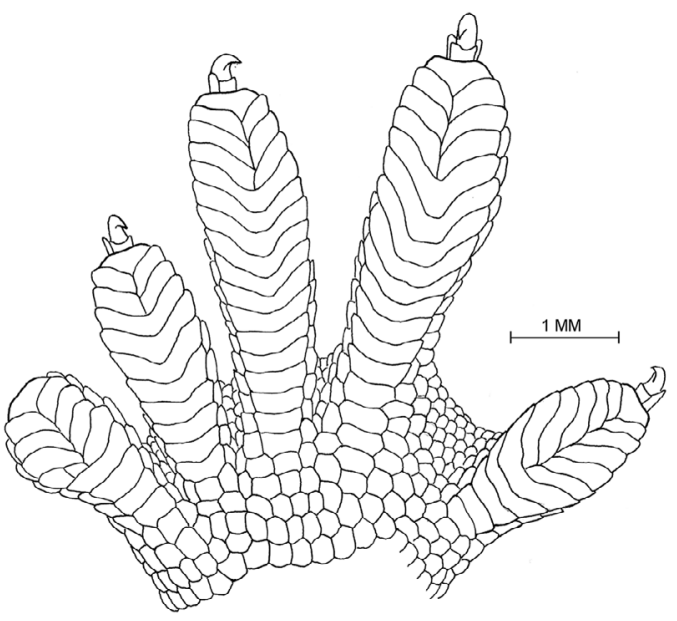

Figure 3. Left hind foot of holotype of L. oligoporus, MCZ R184388.

\section{RESULTS}

Lepidodactylus oligoporus Buden, n. sp. Figures 2-4

HOLOTYPE (Figures 2-4). MCZ R184388, an adult male collected on Toinom Island

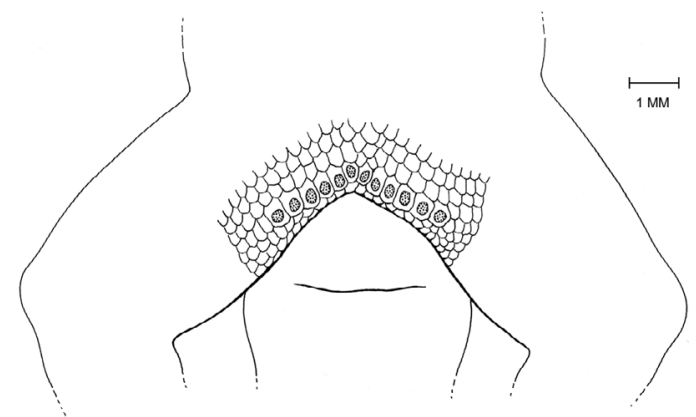

Figure 4. Precloacal/femoral pore scales in holotype of L. oligoporus, MCZ R184388.

(556 $\left.6^{\prime} \mathrm{N}, 153^{\circ} 09^{\prime} \mathrm{E}\right)$, Namoluk Atoll, Mortlock Islands, Chuuk State, Federated States of Micronesia, by D. W. Buden on 20 July 2004.

paratypes. X2948, X2949 (two subadult males) and X2946, X2947 (two adult females), all with same data as the holotype (numbers 
refer to my field tag series); specimens are in the College of Micronesia collections.

DIAGNOSIs. A moderately sized species of the genus Lepidodactylus having a few notched or divided subterminal scansors (thus belonging to Group II); snout-vent length $39.5 \mathrm{~mm}$ in one adult male, $33.8-36.6 \mathrm{~mm}$ in two subadult males, and $40.9-43.2 \mathrm{~mm}$ in two adult females. This species is distinguished from other Group II species by more midbody scale rows (130-134), though fewer than in L. pulcher (143-167), more fourth-toe scansors (15-19), fewer enlarged precloacal/ femoral pore-scales (12-15 in three males), and a moderate amount of interdigital webbing. It is further distinguished from the otherwise very similar $L$. pulcher by fewer interorbital scales (34-35 versus 39-46) and the absence of a spotted head pattern.

etymology. The specific epithet is derived from oligos (Greek) meaning few, and poros (Greek) meaning pore, in allusion to the relatively small number of enlarged precloacal/femoral pore-scales in this species.

DESCRIPTION OF THE HOLOTYPE (measurements in millimeters). Snout-vent length (SVL) 39.5; head length 9.2; head width 5.9; head height 4.2; snout-eye length 4.2; eye length 2.0; eye-ear length 3.6; snout width 1.7; interorbital width 2.0 ; axilla-groin (= trunk) length $20.9 ;$ femoral (= thigh) length 5.8; crus length 4.8; tail length 36.8 ; tail width 3.6; tail depth 2.8.

Snout tapering, rounded at tip; rostral entering nares, roughly quadrangular, approximately twice as wide as deep; nares bordered by five scales: three nasals, rostral, and first supralabial; anteriormost right and left nasals (= supranasals or circumnasals of some authors) separated by single scale bordering rostral; 35 interorbitals (IOS); 10/10 (left over right) supralabials; 11/11 infralabials; mental scale pentagonal, slightly narrower than adjacent infralabials, with two longest sides tending to converge posteriorly before angling sharply to meet posteromedially; anteromedial chin shields about half the size of mental scale except for one much smaller scale intercalated between mental and first left infralabial; lateral chin shields smaller and all gradually reducing in size posteriorly to merge with small, granular gulars.

Body not depressed; 134 midbody scale rows (MSR); dorsal and lateral scales granular, without enlarged tubercles, ventral scales flat, cycloid, 2-3 times larger than dorsal scales; subdigital scansors 8/9, 10/10, 13/12, $12 / 13,10 / 9$ (left over right) on fingers I-V (= FIS-FVS), 9/9, 11/12, 17/17, 17/15, $11 / 11$ on toes I-V (= TIS-TVS); all digits but first clawed (claws somewhat more prominent in Figure 2 than in the specimen); clawbearing phalanges rising above the pad but only the claw free; pads only slightly dilated; interdigital webbing between third and fourth toes moderate (about 1/4 to $1 / 3$ of fourth toe length); enlarged precloacal pore-scales 12 , no femoral pores; actively secreting pores 12 ; cloacal region swollen, hemipenes everted at fixation; cloacal spurs lacking.

Tail (original throughout) subcylindrical, gradually tapering to a point; lateral margins without spines or skin flanges; scales on tail cycloid, annularly arranged and slightly larger midventrally than dorsally and laterally.

COLOR OF HOLOTYPE IN PRESERVATIVE. Upper surface of head brown from snout to interorbital area, posteriorly converging to a middorsal point at occiput; remainder of occiput and neck paler, continuous with pale tan ground color of dorsum; two poorly defined stripes only slightly darker than the ground color (and about 16 scale rows wide) extending entire length of trunk; a series of 7 darker brown irregularly shaped spots on each stripe, roughly matching on each side, from neck to base of tail; lower surface of sides pale grayish brown, grading to the creamy white ventral ground color; ventral scales finely and sparsely stippled with brown when viewed under magnification; a diffuse and discontinuous dark brown stripe extending from posterodorsal border of eye to about level of ear, continuing posteriorly to neck as small, linearly arranged flecks and small patches of brown; another short postocular stripe extending from posteroventral border of eye to about halfway to ear, continuing posteriorly as a diffuse, discontinuous line to base of forelimb; upper surface of forelimbs 
tan, hind limbs slightly paler but mottled with darker brown, especially on anterior and posterior surfaces.

VARIATION. The small sample size (three males, two females) precludes a detailed assessment of intraspecific variation. Comparing the holotype with the four paratypes, all invariably have a single rostral and five scales bordering the nostril, and with one (in the males) or two (in the females) internasals in contact with the rostral. IOS 35 in the holotype, 34 or 35 in the paratypes; MSR 134, 130-134; supralabials $10 / 10,11-12 / 11$; infralabials 11/11, 10-12/11-12; TIVS 17/15, 1519/16-19; enlarged precloacal/femoral porescales 12 (versus 12 and 14 in the two male paratypes); cloacal spurs absent.

The dorsal pattern of the holotype is unique within the type series. The head, trunk, and forelimbs of the two male paratypes are nearly uniform light brown and, as in the holotype, slightly darker on the snout and between the orbits with the darker pigmentation converging to a median point posteriorly at the occiput; the trunk is slightly paler middorsally than laterally. The upper surface of the hind limbs and proximal portion of the tail are gray, somewhat mottled with light brown. The smallest male has a dark brown tail tip. Undersurfaces of head, body, and limbs of the male paratypes are largely similar to those of the holotype.

In the two female paratypes, upper surfaces of the head, neck, and hind limbs are pale gray. The trunk is pale tan with pale gray areas middorsally in one female; a very faint, nearly invisible, indication of stripes and paired blotches suggestive of the bolder pattern of the holotype is in the other. Tan coloration of the trunk extends onto the forelimbs and anteriorly along the sides of the neck, bilaterally in one female and unilaterally on the right side in the other. The venter is pale creamy white and is paler and with less extensive fine brown stippling than in males. Upper surface of tail mottled with pale and dark gray in one, and nearly uniform pale gray proximally and dark brown distally in the other.

distribution. Known only from the type locality. All five specimens were collected at night, about $1 \mathrm{hr}$ after sunset, and from Scaevola taccada shrubs bordering the upper beach zone at the edge of coconut (Cocos nucifera) forest. Toinom Island is 21 ha in area; the total land area of the five islands of Namoluk Atoll is 83 ha.

COMPARIsONs. Lepidodactylus oligoporus differs from many other Group II species in the number of midbody scale rows (130134): in L. gardineri (Boulenger), L. intermedius Darevski, L. lombocensis Mertens, L. paurolepis, L. tepukapili Zug, Watling, Alefaio \& Ludescher, and L. vanuatuensis Ota, Fischer, Ineich, Case, Radtkey \& Zug, MSR does not exceed 121 [combined data from Ota et al. (2000), Zug et al. (2003)], and 91 in the unique holotype of L. shebae (Brown \& Tanner) (counted by Jack Sites, pers. comm.). In contrast, L. pulcher has more, with 153 recorded in Ota et al. (1995) and 143 in Zug et al. (2003), but both counts are based on CAS 139832. MSR counts on the three syntypes of $L$. pulcher (not previously reported in the literature) are 146 and 149 in вмNH 1946.9.8.48 and 49, respectively (Colin McCarthy, pers. comm.) and 167 in MCZ R144392, formerly вмNн 1946.9.8.50 (Ron Clouse, pers. comm.). Lepidodactylus oligoporus overlaps at the upper extreme of L. guppyi Boulenger in this character [117-138 in Ota et al. (2000); 110-133 in Zug et al. (2003)] but is otherwise distinguished from this species in having a greater number of fourthtoe scansors (15-19 versus 9-13) and far fewer precloacal/femoral pore-scales $(30$ or more in L. guppyi; 12-15 in the three L. oligoporus males). It overlaps in MSR also at the upper extreme recorded for L. novaeguineae in Ota et al. (2000) (124-132) but is completely separated in this character using data from Zug et al. (2003) (108-125).

In the number of fourth-toe scansors, $L$. oligoporus (15-19) differs from L. guppyi, L. intermedius, L. lombocensis, L. shebae, L. tepukapili, and L. vanuatuensis, all of which together range from 8-14 based on combined data from Ota et al. (2000) and Zug et al. (2003). It overlaps at the upper range limits of L. gardineri in this character as recorded in both 
Ota et al. (2000) and Zug et al. (2003) (11-17 and $12-17$, respectively) and with $L$. novaeguineae in Ota et al. (2000) (11-16) but is separated from that species using data from $\mathrm{Zug}$ et al. (2003) (10-13). It overlaps broadly with L. pulcher in this character, with 17 to 19 scansors recorded in Ota et al. (2000) and 20 in one specimen examined by Zug et al. (2003).

Lepidodactylus oligoporus differs from all other Group II species except for L. novaeguineae and $L$. pulcher in having no more than 20 enlarged scales in the precloacal/femoral pore-scale row. The three male L. oligoporus have 12-15 enlarged pore-scales, and the number of secreting pores in these specimens varies from 1 or 2 of 14 in the smallest male (a total of 12 or 13 scales being slightly pitted or bearing apparently subsurface secretory material) to 9 of 12 in the next largest male and 12 of 12 in the holotype. Zug et al. (2003) recorded 13-19 secreting pores in 15-19 enlarged scales in two adult $L$. novaeguineae and 16 secreting pores in 16 enlarged scales in one $L$. pulcher. Ota et al. (2000) recorded 16-20 and 18-20 enlarged pore-scales in L. novaeguineae and L. pulcher, respectively. All other species in Group II have at least 20 (and usually far more) enlarged pore-scales.

Lepidodactylus oligoporus has a moderate amount of interdigital webbing between the third and fourth digits on the hind foot (ca. $1 / 4$ to $1 / 3$ the length of the fourth digit), a trait it shares with L. guppyi, L. novaeguineae, L. pulcher, and possibly L. shebae. Brown and Tanner (1949) and Brown and Parker (1977) indicated the extent of webbing in the unique specimen of $L$. shebae as $1 / 4-1 / 3$ and $1 / 5$ the digital length, respectively. Cloacal spurs are not evident in the adult holotype of L. oligoporus nor in the two subadult males. Among the other Group II species, L. shebae is the only one for which no published data are available for states of cloacal spurs. Of the remainder, only $L$. paurolepis and $L$. vanuatuensis exhibit absence of distinct spurs (Ota et al. 2000; H. Ota, pers. comm.), but see also Zug et al. (2003).

Overall, in size and scutellation, L. oligoporus appears most similar to $L$. novaeguineae and $L$. pulcher. It differs from $L$. novaeguineae in having fewer enlarged pore-scales, a larger number of midbody scale rows, and a larger number of fourth-toe scansors, with or without very narrow or no overlaps (see preceding). Also, among the five $L$. oligoporus, three have one internasal and two have two; Brown and Parker (1977) recorded "usually" two internasals present among the $15 \mathrm{~L}$. novaeguineae they examined. Compared with $L$. pulcher, L. oligoporus has fewer enlarged porescales and fewer midbody scale rows. Also, $L$. oligoporus is distinguished from L. pulcher in having fewer interorbital scales (34-35 versus 39-46). Zug et al. (2003) recorded 39 IOS in one specimen of L. pulcher (CAS 139832). Additional IOS counts made on the three syntypes (not previously reported in the literature) are 41 and 42 in BMNH 1946.9.8.48 and 49, respectively (Colin McCarthy, pers. comm.), and 46 in MCZ R144392 (D.W.B., from an enlarged digital image). All other Group II species for which IOS counts are available range from 27 in the unique holotype of L. shebae (Jack Site, pers. comm.) and from 29 to 39 for L. gardineri, L. guppyi, L. novaeguineae, L. paurolepis, L. pulcher, L. tepukapili, and $L$. vanuatuensis [combined data from Zug et al. (2003)]. In addition, none of the L. oligoporus exhibits the distinctive spotted head pattern of L. pulcher remarked on by Boulenger (1885) and Brown and Parker (1977)-see also Boulenger (1885: plate XIII, fig. 5). None of the three syntypes of L. pulcher examined for this study bears a claw on the first digit as illustrated for this species in Figure 2 of Brown and Parker (1977).

\section{DISCUSSION}

Lepidodactylus oligoporus, known only from Namoluk Atoll, Micronesia, is the northeasternmost representative of Group II Lepidodactylus in the Pacific and the second recorded in the nearly $3,200-\mathrm{km}$ east-west span of the Caroline Islands chain, the other being $L$. paurolepis in Palau, approximately $1,900 \mathrm{~km}$ to the west. The two species occupy islands on different submarine platforms-Palau and the main islands of Yap are on the Philippine Plate, whereas the remainder of the Carolines 
(including the Mortlock Islands) to the east are on the Pacific Plate.

Based on mensural and meristic comparisons, L. oligoporus appears most closely allied to $L$. novaeguineae from New Guinea and $L$. pulcher from the Admiralty Islands, its two nearest though still geographically distant neighbors approximately 1,300 and $1,000 \mathrm{~km}$ to the southwest, respectively. But additional morphological and/or molecular comparisons are needed to determine its phylogenetic relationships. Lepidodactylus oligoporus may occur elsewhere in the Mortlocks, if not on the main islands of Chuuk Lagoon, possibly having been overlooked during the largely incomplete biological surveys of this area. The numerous low-lying atolls of the Carolines have very limited land area, impoverished habitats, and low species diversity. Their herpetofauna consists largely of "weedy species," often broadly distributed in Micronesia and, in many cases, well beyond. One possible exception is Perochirus scutellatus (Fischer), which was long thought to be confined to Kapingamarangi Atoll (Buden 1998). However, specimens of a large gecko collected on Ulithi Atoll, Yap, and in the Southwest Palau Islands have recently been identified as $P$. cf. scutellatus (see Wiles 2004).

Both of the Caroline Islands Group II species (L. paurolepis and L. oligoporus) are known from very limited areas and outside of the large main islands in their vicinity. Lepidodactylus paurolepis is known only from several among the "rock islands" of Palau (Ota et al. 1995 ) and L. oligoporus only from a single coralline islet on Namoluk Atoll. No L. paurolepis were encountered during a herpetological survey of Palau Islands subsequent to the collection of the types (Crombie and Pregill 1999), and no other L. oligoporus were among the 61 Lepidodactylus spp. [including at least $L$. lugubris and L. moestus (Peters)] collected by me elsewhere in the Mortlocks during this study, including Nama Island (10), Losap Atoll (1), Ettal Atoll (4), Lukunor Atoll (3), and Satawan Atoll (43). Other Group II species also are known only from very limited areas, including the recently described $L$. $t e-$ pukapili, which is known only from two coralline islets on Funafuti Atoll, Tuvalu (Zug et al.
2003), and L. vanuatuensis, which is probably endemic to Vanuatu (Ota et al. 1998). In addition, L. shebae remains known only from the holotype collected on Guadalcanal Island, Solomon Islands, in 1944 (Brown and Tanner 1949). Such a spotty distribution suggests a relict nature of Group II Lepidodactylus.

\section{ACKNOWLEDGMENTS}

I thank Aaron Bauer, Hidetoshi Ota, and George Zug for responding to numerous questions regarding methodologies in Lepidodactylus taxonomy and for their assistance with the literature. José Rosado and Ron Clouse kindly examined one of the syntypes of $L$. pulcher in the MCZ for me, Colin McCarthy did likewise for the two others in the British Museum, and Jack Sites provided information on the holotype of L. shebae in the Brigham Young University collection. I thank Laszlo Meszoly for drawings of the holotype of $L$. oligoporus. I also thank the librarians at the College of Micronesia, University of Hawai' $i$, and University of Guam, as well as Jens Vindum at California Academy of Sciences for assistance with key literature, and the staff of the Media Instructional Technology Center, College of Micronesia, for assistance in preparing digital images. I am also grateful to the people of the Mortlock Islands for their generosity, many kindnesses, and invaluable assistance during my visits.

\section{Literature Cited}

Bauer, A. M., and K. Henle. 1994. Family Gekkonidae (Reptilia, Sauria). I. Australia and Oceania. Das Tierreich, Teilband 109. Walter de Gruyter, Berlin, Germany, and New York.

Bergmann, P. J., and A. P. Russell. 2003. Lamella and scansor numbers in Thecadactylus rapicauda (Gekkonidae): Patterns revealed through correlational analysis and implications for systematic and functional studies. Amphib.-Reptilia 24:379-385.

Boulenger, G. A. 1885. Catalogue of the lizards of the British Museum (Natural History). Vol. 1. Geckonidae, Eublepharidae, 
Uropeltidae, Pygopodidae, Agamidae. Taylor and Francis, London.

Brown, W. C., and F. Parker. 1977. Lizards of the genus Lepidodactylus (Gekkonidae) from the Indo-Australian Archipelago and the islands of the Pacific, with descriptions of new species. Proc. Calif. Acad. Sci. 41:253-265.

Brown, W. C., and V. M. Tanner. 1949. Rediscovery of the genus Pseudogekko with description of a new species from the Solomon Islands. Great Basin Nat. 9:4145.

Buden, D. W. 1998. Morphological variation and distributional ecology of the giant $\mathrm{Mi}$ cronesian gecko (Perochirus scutellatus) of Kapingamarangi Atoll. Pac. Sci. 52:250258.

Crombie, R. I., and G. K. Pregill. 1999. A checklist of the herpetofauna of the Palau Islands (Republic of Belau), Oceania. Herpetol. Monogr. 13:29-80.

Ineich, I. 1999. Spatio-temporal analysis of the unisexual-bisexual Lepidodactylus lugubris complex (Reptilia, Gekkonidae). Pages 199-228 in H. Ota, ed. Tropical island herpetofauna: Origin, current diversity, and conservation. Elsevier, Amsterdam.

Ota, H., I. S. Darevsky, I. Ineich, and S. Yamashiro. 2000. Reevaluation of the taxonomic status of two Lepidodactylus species
(Squamata: Gekkonidae) from the Lesser Sunda Archipelago, Indonesia. Copeia 2000:1109-1113.

Ota, H., R. N. Fisher, I. Ineich, and T. J. Case. 1995. Geckos of the genus Lepidodactylus (Squamata: Reptilia) in Micronesia: Description of a new species and reevaluation of the status of Gecko moestus Peters, 1867. Copeia 1995:183-195.

Ota, H., R. N. Fisher, I. Ineich, T. J. Case, R. R. Radtkey, and G. R. Zug. 1998. A new Lepidodactylus (Squamata: Gekkonidae) from Vanuatu. Herpetologica 54:325-332.

Radtkey, R. R., S. C. Donnellan, R. N. Fisher, C. Moritz, K. A. Hanley, and T. J. Case. 1995. When species collide: The origin and spread of an asexual species of gecko. Proc. R. Soc. Lond. 259:145-152.

Uetz, P., R. Chenna, T. Etzold, J. Goll, and J. Hallermann. 2005. The EMBL reptile database (http://www.reptile-database.org). Accessed 28 November 2005.

Wiles, G. J. 2004. A record of Perochirus cf. scutellatus (Squamata: Gekkonidae) from Ulithi Atoll, Caroline Islands. Micronesica 37:163-166.

Zug, G. R., D. Watling, T. Alefaio, S. Alefaio, and C. Ludescher. 2003. A new gecko (Reptilia: Squamata: genus Lepidodactylus) from Tuvalu, south-central Pacific. Proc. Biol. Soc. Wash. 116:38-46. 